\title{
From health to wealth : The future of personalized medicine in the making
}

\section{Tarkkala, Heta Anna Ulrika}

2019-05-20

Tarkkala , H A U , Helen , I A \& Snell , K 2019 , ' From health to wealth : The future of personalized medicine in the making ' , Futures , vol. 109 , pp. 142-152 . https://doi.org/10.1016/j.futures.2018.06.00

http://hdl.handle.net/10138/330113

https://doi.org/10.1016/j.futures.2018.06.004

cc_by_nc_nd

acceptedVersion

Downloaded from Helda, University of Helsinki institutional repository.

This is an electronic reprint of the original article.

This reprint may differ from the original in pagination and typographic detail.

Please cite the original version. 
FINAL DRAFT, ACCEPTED FOR PUBLICATION IN FUTURES $(109,142-$ 152).

\title{
From Health to Wealth: The Future of Personalized Medicine in the Making
}

Heta Tarkkala/ CORRESPONDING AUTHOR,

University of Eastern Finland, University of Helsinki, (Department of Social Sciences, P.O. Box 111, 80101 Joensuu, Finland / heta.tarkkala@ helsinki.fi)

\section{Ilpo Helén,}

University of Eastern Finland (Department of Social Sciences, P.O. Box 111, 80101 Joensuu, Finland ilpo.helen@uef.fi)

\section{Karoliina Snell}

University of Helsinki (Department of Social Research, P.O Box 18, 00014 University of Helsinki, Finland karoliina.snell@helsinki.fi)

Funding: This work was supported by the Academy of Finland [grant numbers 292408; 292456] and Tekes - The Finnish Funding Agency for Innovation [grant number: 3986/31/2013].

\begin{abstract}
During the past decade, in Finland and elsewhere, biomedicine and genomics-related initiatives have been organized under the sociotechnical imaginary of personalized medicine. Within this imaginary, the medical future is promoted and made up, and the activities often subtly change the very meaning of what the imaginary of personalized medicine entails. In this paper, we study the Finnish strategies and pursuits addressing the utilization of genomics to advance personalized medicine. We build our analysis on previous research on sociotechnical imaginaries (Jasanoff \& Kim, 2015) and the hype and expectations surrounding emerging technologies (Brown, 2003; Brown \& Michael, 2003; Borup et al.,
\end{abstract}


2006). We emphasize that the sociotechnical imaginary requires practical maintenance. In our analysis we address both rhetorical and action framings related to the making of personalized medicine and point out that activities of maintenance simultaneously pursue and reconfigure the imaginary of personalized medicine. Furthermore, our analysis shows that the focus of advocacy in personalized medicine has shifted from the promise of health to the promise of wealth as innovation policy and data-driven medicine have become the key framings.

Keywords: expectations, innovation policy, genomics, data-driven medicine, personalized medicine, policy framing

\section{Introduction}

Biomedicine is future oriented and promissory; it comes with expectations of better treatments, more accurate diagnostics and prevention of diseases (see, e.g., Hamburg \& Collins, 2010; Hood \& Friend, 2011; Swan, 2012). Indeed, many STS studies on cutting-edge biomedicine and other emerging technologies have deployed expectations, hypes, hopes, and promises as analytical concepts (e.g., Borup et al., 2006; Brown, 2003; Brown \& Michael, 2003; Fortun, 2008; Fujimura, 2003; Hedgecoe, 2004; Helén, 2013; Novas, 2006; Sunder Rajan, 2006). These studies emphasize that impressive advances in high-tech medicine are essentially based on their "power to raise hopes for new cures and better life in people" (Helén, 2004, p. 4). In this paper, we study the making of a medical future in the activities done to advocate for personalized medicine in Finland during the past decade.

In the wake of the Human Genome Project (HGP), great expectations were attached to human and medical genomics. A decade after the completion of HGP, fulfilment of the 
promises has been repeatedly postponed (Burke et al., 2010; Guttmacher \& Collins 2005; Lander 2011). Still, the expectations should not be considered mere hype. As many studies have pointed out (Borup et al., 2006; Brown \& Michael 2003; Fujimura, 2003; Helén, 2013; Sunder Rajan, 2006; Van Lente, 2012), expectations make things happen. They have the power to direct interests; they justify certain $R \& D$ projects or programs and make them attractive to funding institutions and investors. Expectations point out certain directions and paths for the future and, while doing so, reduce uncertainty. They also have the power to coordinate, as they bring actors, institutions, and resources together; organize practices and communities; and keep networks wired.

Jasanoff and Kim $(2009 ; 2015)$ use the concept of sociotechnical imaginaries to capture the relationship between social expectations and the development of science and technology. The concept refers to "collectively held, institutionally stabilized, and publicly performed visions of desirable futures, animated by shared understanding of forms of social life and social order attainable through, and supportive of, advances in science and technology" (Jasanoff, 2015a, p. 4). Jasanoff (2015b, p. 322) suggests that empirical analyses of sociotechnical imaginaries should be focused on "where transformative ideas come from, how they acquire mass and solidity, and how imagination, objects and social normsincluding accepted modes of public reasoning and new technological regimes-become fused in practice". We conceive of personalized medicine (see ESF, 2012; Tutton, 2014) as a sociotechnical imaginary of contemporary biomedicine that labels the expected changes. Personalized medicine is what is to come and what needs to be acted on for societies in Europe and elsewhere to care for their citizens appropriately (European Commission, 2013; OECD, 2013). 
The imaginary of personalized medicine is a landscape in which medical genomics is assembled, policies are shaped, and scientific endeavours are carried out, both in Finland and elsewhere. We analyse how this sociotechnical imaginary is fused in practice by studying Finnish strategies that pursue the promises of genomics and personalized medicine. Our article contributes to the analyses of sociotechnical imaginaries (Jasanoff \& Kim, 2015) and the discussion about hype and expectations surrounding cutting-edge technoscience (Borup et al., 2006; Brown, 2003; Brown \& Michael, 2003). We focus on the practical dimensions and measures by which the imaginary is promoted and maintained. Jasanoff (2015a, p.10) remarks that the "mechanics of the interconnections between technoscientific and political practice have not been

articulated in detail or systematically", especially not in relation to innovations. In this paper we show that national strategies perform and produce visions that are mutually constitutive with the sociotechnical imaginary (see Jasanoff 2015a, p. 11, 14). Our empirical case is an excellent example of such co-constitution because the promotion of personalized medicine is an intensely state-driven and national endeavour in Finland. We also contribute to the discussion on expectations by analysing how a sociotechnical imaginary moulds over time.

The train of thinking for our study is as follows: Surely, expectations shape practices within the sociotechnical imaginary of personalized medicine. They have the power to modify how present resources are reconfigured and reorganized to point toward a particular future and even to mobilize that future today (Brown, 2003, p. 5). However, the power of expectations is not merely performative (cf. Borup et al., 2006; Van Lente, 2012). To be effective, expectations need to be articulated through and embedded in practical measures for pursuing personalized medicine in concrete ways and in actual political, economic, medical science, and health care settings. We analyse the performative and practical aspects of our case with the help of policy framing analysis (e.g. Fischer, 2003; Hajer, 2003, Schön \& Rein, 1994; for an overview, see van Hulst \& Yanow, 2016) By framing, we refer to an interpretative scheme for problem-setting and sense-making in policymaking and governance. We talk 
of framing instead of frames as we want to emphasize the processual and constructive character of articulation of meanings, problems, values and agendas in policy-making (van Hulst \& Yanow 2016). Following Schön and Rein (1994), we make a distinction between two levels of framing upon expectations. The first level-rhetorical framing-comprises of general schemes of persuasive argumentation that describe and organise how the expectations, promises and advocacy of personalized medicine are attached to certain objects, objectives, activities, and actors in a consistent and justifiable way. The second level of framing-action framing-informs more directly policy programs and implementation. Within action framing, specific expectations and practical steps and demands for achieving personalized medicine are defined and outlined. Altogether, the concept of framing enables us to grasp the practical or even material side of the sociotechnical imaginary of personalized medicine. With the help of the concept we can analyse how reasoning, strategies, and practices of implementation are connected. In addition, framings allows us to see the dual nature of the practice of putting expectations into action: they work both to make the future and to keep up expectations.

Expectations attached to biomedicine have to be constantly maintained and iterated by means of science, politics, administration, and commerce. Such pursuits to govern and maintain multiple expectations are oriented toward a future that is not conceived of in terms of progress but rather as opportunities involving unpredictability and uncertainty. They designate practices to keep the future open by creating prospects and by pointing out and mobilizing opportunities and resources that biomedical R\&D, clinical care, business, health care management, policymaking, and even personal self-help may utilize (Helén, 2013).

When scientific, administrative, political, and business-making etc. practices search for, open up, and create opportunities and harness the potential for, for example, personalized medicine they bring together many kinds of stakeholders and actors to pursue biomedical 
innovations in global and local settings. In a wide range of studies on public policy and administration, organizations, and corporate management, governance has become a nearly catchall concept to refer to such activities. By governance, many scholars emphasize the processual character and open-endedness of policymaking, management, or organization reforms. It means practices of governing by which the interests, goals, activities, and powers of multiple stakeholders are managed, balanced, and combined in the process of making and executing a policy or a reform (e.g., Bevir, 2012). Constant evaluation of the process and its achievements and outcomes as well as readjustment of the objectives are also seen to characterize governance (e.g., Jessop, 1998; 2002). Practices to maintain the promise of personalized medicine share many of these features and, from the perspective of governance studies, they can be seen as governance of innovation.

Recent literature on innovation governance (e.g., Deschamps \& Nelson, 2017) emphasizes systems, models, leadership, and top-down management of innovative activities. Our study points to a somewhat different direction. Practices and rationales promoting personalized medicine entwine and enmesh multiple activities with each other, such as business, from financing to marketing, resource and personnel management, scientific research, product development, consulting, and public governance and policymaking, while seeking to manage many sorts of expectations. This kind of innovation and technology governance has a particular feature - namely, it involves experimenting with existing epistemic, professional, institutional, political, legal, administrative, and business orders (Helén 2013). By pointing this out, we want to emphasize that practices dealing with the future include unpredictable and unintentional elements..

In the domains of medicine and health care, the mentioned practices of governance manifest themselves by, for example, endless rearrangements of environments and 
assemblages of biomedical science, medical business, and clinical care in local, national, and transnational settings. In this paper, we take a closer look at this particular configuration by analysing how governance of and by expectations work and configure in pursuits to sustain and promote medical genomics under the imaginary of personalized medicine in Finland. In particular, we are interested in how such governance reconfigures the sociotechnical imaginary. We study actual strategies, "roadmaps", proposals for and projects involving experimentation, iteration and implementation of techniques, and practices of the future medicine in Finland, with a focus on reasoning over the objectives, milestones, measures to be taken, issues to be improved, and resources to be mobilized for becoming of personalized medicine. In particular, we study the framings within which expectations about the future of personalized health care are aligned with the ongoing creation of large depositories of digital health data.

The performative effectivity of a sociotechnical imaginary requires practical maintenance. We conceive of the efforts to advance personalized medicine as such maintenance. Through our analysis, we want to back up two claims about expectations as related with governance and policy-making on biomedical technology. First, in practices of promoting and seeking opportunities to advance personalized medicine, sustaining prospects is a crucial task that is seemingly more important than the actualization of promises as actual outcomes, including scientific results or new health care products. Second, our case shows that such maintenance requires the reshaping of expectations, the readjustment of prospects, and setting them in new contexts with new alliances. Thus, the actual work-both performative and practical—upon the expectations for personalized medicine constantly redefines the sociotechnical imaginary itself. 
Our paper unfolds as follows: In the next section, we introduce the data on which our analysis is based on and our research methods; after that, we outline the Finnish strategies to promote medical genomics and personalized medicine during the past decade. In Section 4, we analyse the currently predominant frames of reasoning for promoting personalized medicine, and Section 5 focuses on the practical implementation required to make personalized medicine and its benefits happen. In the concluding section of the paper, we discuss the characteristics of governance of biomedicine in light of our case, Finland. We emphasize that the practices and the rationale of governance support and maintain the sociotechnical imaginary of personalized medicine by modifying and gradually changing it.

\section{Materials and Methods}

The research material analysed for this article consists of (a) the main Finnish strategy papers and reports that outline and evaluate policies related to biomedicine and health technology from 2005 to $2016(\mathrm{n}=13)$ (see figure 1); (b) press releases and news posts related to the strategies, biobanks, and the genome centre in Finland $(n=9)$ from 2014 to 2017; and (c) presentation slides by different stakeholders and field notes from seminars and events concerning health technology, biobanks, and genomics from 2013 to 2017 ( $n=18$ ). The analysed strategies represent the most influential and cited policy frameworks that are guiding the development of national infrastructure and strategic funding. In these texts, the future of Finnish health care, medical genomics, and biomedicine are envisioned from scientific, political, administrative, medical, and commercial perspectives. The main corpus of the strategies analysed comprises documents published from 2013 to 2017 . Our analysis of the documents showed that that the gradual shift of emphasis from health to wealth during this time — which we identify in our analysis—-became more intensified and apparent in the strategy and policy papers. The main publishers of these strategies were the Ministry of 
Education (ME), the Ministry of Social Affairs and Health (MSH), and the Ministry of Economic Affairs and Employment (MEE).

We collected and utilized the other two types of materials only from the period of 2013-2017 to illustrate our point and give further depth to our analysis. We used press releases and news posts from the Internet related to the publishing of the strategies and reports or those published by Finnish biobanks and key funding agencies to describe and promote the Finnish health business and ecosystem (such as www.finlandhealth.fi and www.sitra.fi). These posts and the presentation slides used in seminars and events were collected from the Internet, or notes were made from them along with participant observations. We have been following the field since the early 2000s in Finland, and our analysis is informed by our experience and different projects in which we have been involved (see Lauss et al., 2011; Lehtimäki et al., in press; Tupasela et al., 2015). In these projects, we have followed closely the development of biomedicine, biobanking, and medical genomics in Finland. We have, for example, participated in seminars, events, and meetings related to the topic, where we have listened to presentations by different stakeholders and made field notes. The empirical material forms a corpus that represents the official Finnish strategy framework as well as how stakeholders such as biobanks and funding agencies reproduce the framework in their own materials and presentations.

First, we read through all of the strategy papers and analysed them thematically through inductive qualitative content analysis. Then, we constructed an analytical timeline that describes how the overarching imaginary of personalized medicine was presented and took new forms in the material. The timeline also points out what kind of promises and expectations were articulated, and on what the expectations were placed in each phase or strategy. From this, we identified two recurring general framings that featured a distinctive 
rhetorical style and argument: innovation policy and data-driven medicine. Within the innovation policy framing, the expectations of personalised medicine were primarily associated with economic value, growth and competitiveness. Data-driven medicine framing highlights the possibilities of public registers, databases and digitalisation to enhance personalised medicine and presents these resources as unique elements of Finnish society. Both of these rhetorical framings became more intensified and prominent from 2013 onward.

As we are particularly interested in the practices required to achieve personalised medicine, we also examined more specific expectations and identified three action framings that apply to domains of both innovation policy and data-driven medicine: Centralization of data management, modification of clinical and administrative practices to serve data collection, and creation of enabling regulation. Both levels of framing we found, cover both performative and practical aspects of sustaining personalized medicine. Within the framings, not only visions and objectives are created and reasoned over, but also concrete measures and action plans are outlined and discussed. After identifying the framings in the strategy papers, we applied them on the press releases, news, and seminar and conference presentations, and we found out that the two-level framings were present in them, too.

Our analysis focuses on Finland, but similar strategies to harness the potential of genomics are being developed in other countries as well, for example in Sweden (Cool, 2016), Great Britain (https://www.genomicsengland.co.uk; https://www.gov.uk/government/publications/life-sciences-industrial-strategy), Singapore (Ong, 2016), Canada (http://www.genomecanada.ca), and Denmark (Ministry of Health 2017). Thus, the Finnish case illustrates a more general tendency to attribute economic value to population, genomics, and health data.

\section{National Strategies: Creating Value for Science, Health Care, and Commerce}


Before going into the framings, we first describe the major strategies and milestones from the past decade (see Figure 1). The first strategy papers in our material formulated genomics as a rising field with huge scientific and medical potential. Biobanks were regarded as offering a practical possibility to enhance genomic research and medicine, and preparation for a biobank act started in 2006. Concomitantly, up until 2013, expectations of personalized medicine were placed on biobanks and biobank networks, which were seen as the platform on which to build up personalized medicine. After years of preparation, the Biobank Act (2012) was passed to respond to "an increased interest in the potential offered by biobanks" (MSH, 2011b). After 2013, when the act was first enforced, 11 biobanks meeting the requirements of the law have been founded. Two of them have since merged, and the latest biobank included in the register is the first private biobank in Finland. While some biobanks have operated since 2014, many of the biobanks have only started to collect new samples during the last year or have not yet begun to collect samples.

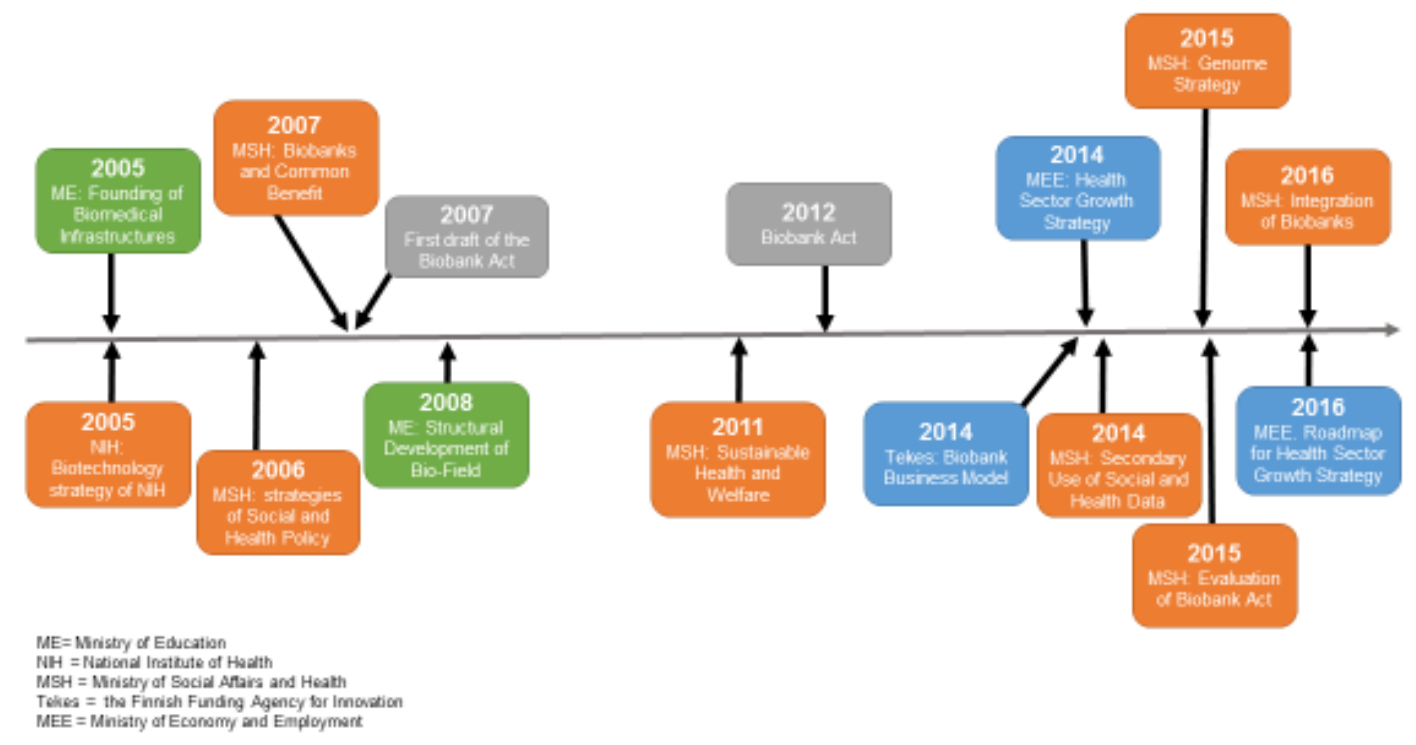

Figure 1. Timeline of main strategies and the development of regulation in Finland 2005-2016. 
The visions of advancing personalized medicine through biobanks have changed considerably, even before the initial visions have been concretely implemented. The earlier pursuit of covering Finland with regional biobanks linked to university hospitals and hospital districts has been replaced by a vision of a "Biobank Finland". Two years after the registration of the first biobanks, an expert group was appointed to evaluate the possibility of integrating the biobanks. The objective of the group's report on integration was to assess the nationwide coordination and integration of Finland's biobanking resources to optimize the realization of value for science, health care, and commerce. In practice, the report and the discussions leading to it were looking for ways to either merge or create tighter and more standardized cooperation of biobanks that would result in the forming of the legal entity"Biobank Finland"- that could better serve the needs of industry and research groups in gaining access to data. The expert group formulated the rationale behind the change in the following way:

... leveraging the full potential of biobanking in Finland as a national resource will only be realized if individual biobank resources are integrated as parts of an overarching ecosystem that, by virtue of creating interoperability, results in critical mass. (MSH, 2016b)

Parallel to the developing of biobanking, a proposal for a national "genome strategy" was published in Finland in the spring of 2015. Its aim was to set "key measures for ensuring that, by 2020, genomic data will be effectively used in health care and in the promotion of health and wellbeing" (MSH, 2015, p. 3). The strategy proposal presented visions of how to harness the potential of genomic data in Finland. It was the result of a collaborative process involving an appointed working group and workshops open to medical, scientific, administrative, and commercial stakeholders. The preparation of the strategy was initiated 
and backed up by the Ministry of Social Affairs and Health and the Finnish innovation Fund Sitra, an independent fund reporting to the Finnish Parliament. Sitra's mission is to invest in and direct efforts aimed at "building a successful Finland for tomorrow" (www.sitra.fi).

The initial aim and tight schedule of the strategy process were planned to coincide with the forming of a new government, and the hope was that the strategy would be integrated into the government programme. However, the strategy was left out of the programme, to the disappointment of the actors involved in the drafting process. Despite the setback, the strategy was kept alive and lobbied for, and a year later, government funding was directed to establishing a "national genome centre". In the Genome Strategy, such a centre was identified as a major milestone.

A government statement stated:

A Genome Centre will be established in Finland, aimed at developing Finland into a pioneer and internationally desired partner in health care, high-level research and global business utilizing genome data. Public biobank activity will be enhanced by standardizing operating methods and ensuring effective cooperation with the Genome Centre. (Finnish Government, 2016)

The Genome Strategy and the genome centre are part of the current future visions of biomedicine, and articulate the imaginary of personalized medicine. The imaginary is built on preceding visions (see Jasanoff \& Kim, 2015) and expectations of Finnish medical genomics, biobanks, and biomedicine in general (see Tupasela, 2006), but it also promotes an idea that biobanking is not enough for achieving personalized medicine. The Genome Strategy is closely linked with other strategic endeavours in Finland that are implemented and revised simultaneously, and they are pushed and supported by the same actors. Thus, the strategies 
are interconnected. The other main endeavours today are the Health Sector Growth Strategy (MEE, 2014), the secondary use of social and health data legislation (MSH, 2014), and plans for a national Digital Health HUB (Sitra, 2016). The Health Sector Growth Strategy (MEE, $2014 ; 2016)$ is an overarching policy framework that places high expectations on genomic data and personalized medicine. It emphasizes Finland's potential to become a forerunner and internationally attractive partner for global business, cutting-edge research, and health care utilizing genomic knowledge. Additionally, it states that strong national coordination and common infrastructures and institutions are needed for full-scale utilization of genomic knowledge and biobank resources.

While the new social and health data legislation would make it possible to reuse health and social data, the HUB would collect and distribute health, social, and welfare data from a variety of public databases. The HUB is also planned to function as a single access point to the data that serves medical research and development—-both public and private, scientific or commercial - from Finland and abroad. The plans envision that the biobanks and genome centre would also be connected to the HUB, but simultaneously, there is a considerable lack of clarity about what this would mean in practice.

As 2020 approaches, the realization of the vision of personalized medicine and fulfilment of the promises of medical genomics are increasingly being directed by ideas and projects in the national innovation and growth strategies. As the former flagships, biobanks are still part of these new visions, but they are now expected to form an integrated entity and be more closely connected to the forthcoming Genome Centre, the digital health HUB, and even a Comprehensive Cancer Centre (FICAN), which received funding in the same package with the Genome Centre and biobanks in 2016. In biobanks' current state, their potential is no longer regarded as being enough to sustain expectations and create a new competitive edge. 


\section{Framing the Promise}

A sociotechnical imaginary like personalized medicine requires framings to become effective and "fused in practice" (Jasanoff, 2015b, p. 322). The strategy papers we analysed provide two predominant framings for the prospects of genomics as personalized medicine in Finland. They reflect changes in the reasoning by which medical genomics is promoted. The first framing is innovation policy, which emphasizes economic and commercial aspects of medical genomics, and the second one is data-driven medicine. Currently, the realization of the promise hinges less on biomedical research and usage of tissue samples, and more on competitive usage of health related data.

Already in the early 2000s, the advocates of medical genomics presented research as an important element of the Finnish "knowledge-based economy" and "innovation system", and the makers of innovation policy considered medical genomics to have considerable business potential (Snell, 2009; Tupasela, 2006). At this point, much attention was given to scientific potentials, future health care, and public health at the side of this commercial potential (Käpyaho et al., 2004; Palotie \& Peltonen-Palotie, 2004). However, during the past decade, the innovation policy framing has intensified and slowly overshadowed the justifications and rationales related to the advancement of biomedical science and public health. Within the innovation policy frame, Finland is seen to have assets that give Finnish researchers, research institutions, and companies an advantage over their competitors abroad. Among them are the unique genetic makeup of the Finnish population, extensive and systematic electronic patient records from public health care, electronic national population and health registers, cutting-edge medical genomics with advanced biobanks and biobank legislation, a public health care system, and popular trust in authorities and medical science (MSH, 2015; Sitra, 2015). According to this intensified innovation policy rationale, these 
factors make Finland an environment for biomedical R\&D that cannot be found anywhere else in the world —-"your test bed for research and medical innovation" (Sitra, 2015).

Finland's assets are primarily seen in terms of commercial potential and prospective economic gain. The "uniqueness" of the Finnish R\&D environment is considered—and hoped - to attract international pharmaceutical and other medical enterprises and investors, which would increase business opportunities for Finnish researchers, companies, and start-up entrepreneurs. For years, innovation and commercial potential have been present in the development strategies of genomics, biobanks, and personalized medicine; however, the innovation policy framing has previously complemented health and social welfare objectives, as an R\&D policy definition by the MSH in 2011 outlined: "Reinforcing the foundation for the welfare of a socially sustainable society, promotion of equal treatment, and a healthy and safe living environment are also the main strategic goals in R\&D\&I” (MSH, 2011a).

In the proposal for the Genome Strategy (MSH, 2015) and in the Health Sector Growth Strategy (MEE, 2014), the expectations for personalized medicine are articulated more explicitly and concretely through innovation policy and commercial framing than in regards to public health and health care. These documents are emblematic of the trend in the Finnish discussion of justifications related to science and health care being eclipsed by economic and business rationales. Simultaneously, the producer of the strategies changed; whereas it was Ministry of Education from 2005 to 2007 and the Ministry of Social Affairs and Health from 2007 to 2011, it is nowadays the Ministry of Economy and Employment. In the current frame of innovation policy, plans to develop biobanks, genomics, and high-tech medicine are aimed at making the "innovation ecosystem" of Finnish biomedicine more efficient and vibrant. As a result, both the scientific and —in particular-commercial potential of medical R\&D could be actualized, and the advantage over competitors would not be lost. 
In particular, the idea of the national HUB facilitating the circulation of Finnish health data is embedded in a commercial rationale. The HUB is thought of as a way to provide international pharmaceutical corporations and other medical enterprises with easy access to all Finnish health databases, collections of human tissue samples, and related patient data, which would boost collaboration in biomedical R\&D between Finnish expert institutions and international business partners. Thus, the development of infrastructure for biomedical research is driven by a focus on the economic and commercial prospects of science. This has been a significant policy framing of genomics, biobanks, and biomedicine in many countries for two decades, starting from deCode Genetics Ltd and the Health Sector Database in Iceland (Fortun, 2008; Ong, 2016; Sunder Rajan, 2006).

These Finnish strategies not only define the expectations of biobanks, medical genomics, and biomedical research in terms of innovation policy and commercial prospects but also entwine this framing with an understanding of genomics as part of data-driven medicine. This is the second current framing of the promise of personalized medicine. When biobanks were envisioned, planned, and discussed in different countries at the end of the 1990s and the early 2000s, they were primarily seen as tissue collections serving large-scale DNA sequencing (e.g., Palotie \& Peltonen-Palotie, 2004). Parallel to the actual efforts of founding and maintaining biobanks and biobank networks during the past decade, the focus has shifted from them being depositories of tissue samples to being digital databases to enable the combination and circulation of data from tissue sample collections, patient records, and population registers (NAS, 2011; Weber, Mandl, \& Kohane, 2014; on a similar tendency in life sciences in general, see Leonelli, 2016). Likewise, molecular biology is being eclipsed by bioinformatics as a key technology of medical genomics (Douglas, 2014; Suárez-Diáz, 2010; Zerhouni, 2005). This trend is partly a result of the fascination of influential advocates of biomedicine in Big Data and rapid advances in IC technology for computation and 
management of digitalized data (e.g., Hood \& Friend, 2011; Topol, 2012). As a result, genomics, with its large-scale data-mining projects, has become a part of data-driven medicine; consequently, the sociotechnical imaginary of personalized medicine has been almost completely coloured by expectations attached to ICT capacity to collect, manage, and compute more kinds of health-related data (e.g., Swan, 2012).

Development in Finland has followed a similar path. The establishment of Finnish biobanks, building up of the national health record archive Kanta, and launching of projects for translational genomics were parallel processes in the early 2010s. They have been directed by a rationale according to which developments in medical research and care inevitably lead toward data-driven medicine. This is expected to improve clinical care and prevention, increase the cost-effectiveness of health care systems, and provide more precise and patient-centred medical knowledge. In congruence with the new focus on the promise of personalized medicine, the strategy papers have redefined the assets and competitive advantages — both scientific and commercial—Finland has in the global field of medical genomics. Framed by the expectations attached to data-driven medicine, well-maintained electronic patient registers, digitalized hospital data archives and national health and population registers that cover many decades are now seen as the specific features of the Finnish medical R\&D environment.

Finland is considered to be in an especially good position as a leading country in the so-called personal health care research. Research and know-how are at a high level and have available globally unique comprehensive databases about national health. This potential should be utilised. (MEE 2014, 3)

Furthermore, the extensive possibilities to carry out combinations of biological data and patient data in a smooth and accurate manner make Finland "unique". This rise of the 
importance of data is already reflected in the need to re-evaluate the Biobank Act from the day it was put into force. The legislation process had taken such a long time that when the law was finally enacted, it did not meet the needs anymore. For example, it was considered too sample centric, which also formed a background to the different projects, initiatives, and openings done in the name of making Finnish health data available (Tupasela et al., 2015).

The advocates assume that Finnish biobanks and medical genomics are attractive to international scientific and commercial partners due to the availability of "real-life data". Furthermore, Finland's competitive advantage does not lie merely in data collections per se but in the expertise in managing of such data. Scientific and commercial partners are believed to be interested in combined datasets. Finnish biobanks and the medical genomics research community have developed data-management practices that combine sample management, bioinformatics, and administrative expertise. Demand for such expertise in digital data management has grown immensely, as research in life sciences and biomedicine has become oriented toward handling and mining large datasets with the help of ICT (see Leonelli, 2013; 2016).

A key claim in the promotion of genomics-based personalized medicine is that healthrelated data is both unique in their extent and quality and easy to access and manage for R\&D purposes in Finland. The high hopes and big claims related to the Finnish health "Big Data" are embedded in a long history of public authorities keeping population and health registers and statistics, extending back to the 18th century. The first computerized national disease register, the Cancer Register, was established in 1952. Statistics Finland and the National Institute of Health and Welfare (THL), as public authorities, facilitated the use of register data in a wide range of medical and social studies during the latter half of the 20th century (Gissler \& Haukka, 2004). In addition to the national databases, public hospitals and 
health care districts have systematically kept patient record archives since the early 20th century, and the majority of patient records and data about medical care have been stored in electronic form for three decades in Finland. THL and the Social Insurance Institution of Finland have compiled data from hospitals, health care centres, health insurance compensations and pensions, and prescriptions, and the national patient record and prescription archive Kanta has been in operation since 2010. This vast amount of health data that has already been collected in Finnish public databases, combined with the data in biobank depositories, is seen to be Finland's main asset in making the Finnish biomedical “innovation ecosystem" competitive and attractive to collaborators and investors.

In the 2010s, the term national treasure, referring to public health databases, spread throughout the biomedical and genomic strategies. Strategic documents attempted to show what different stakeholders should do to actualize the scientific, medical, and above all, commercial potential of the Finnish health data to transform "a pile of ore into a treasure" (Hämäläinen, 28.10.2016). Such a metaphor creates an association between public health databases and Finnish natural resources, like forests being "green gold" to the forestry industry, which has been the backbone of the Finnish export economy since WWII. In the sociotechnical imaginary of data-driven personalized medicine data, people — or the population providing biological and health data - and the public institutions that generate and collect that data are considered natural resources that stakeholders from biomedical business can appropriate and utilize. Within the transnational field of personalized medicine, the Finnish imaginary is emphatically framed as a national effort.

\section{Framing the practical measures}

The strategies and roadmaps include many practical measures to harness this national treasure. Despite the expectations, the Finnish health data reservoir has not been fully 
appropriated. On the one hand, the potential for combination of data from different digital databases and depositories is seen as enormous. On the other hand, only a fraction of this potential is currently utilizable. Consequently, the standardization, coverage, and effectiveness of Finnish health care institutions in collecting, managing, and circulating patient and "-omics" data should be vastly improved. Specifically, "the full potential of biobanking in Finland can only be realized if the three requirements outlined above can be met: standardization/integration, annotation with EHR/EMR [electronic health record/electronic medical record], and funding to attain critical mass" (MSH, 2016b, p. 5).

The roadmaps outlined in the strategy papers consist of three main elements that we identified as action framings: centralization of data management, modification of practices to serve data collection, and the creation of enabling regulation. First, almost all papers share the view that resources need to be concentrated into large units to realize their full potentialwhether through the integration of biobanks or the centralization of data management, as we described above. Centralization does not mean closing down regional and other biobanks but coordination of their data depositories, harmonization, and unified access procedures for the biobank data as well as appropriation, circulation, and combination of the data with other health databases under a common service provider and the national Health Data HUB. These plans are attempts to achieve a main goal of the health sector growth strategy (MEE, 2014), namely enabling easy access to personal health data and patient documents for $R \& D$ purposes: "The plan is to harness these data resources, which are unique by international standards, for more extensive use and utilization closer to the individual. Information from different sources should be offered smoothly, following the so-called one-stop shop principle” (MEE, 2016). 
The second action framing concerns health care institutions. The visions of datadriven personalized medicine and policy promoting view the public health care system from a new perspective. Regarding innovative biomedical $R \& D$, hospitals, health care centres, and clinical laboratories are primarily important and valuable as suppliers of patient data and as sites for experimentation and trials. To enhance this value potential, health care institutions have to be reformed to become compatible with the "health sector innovation ecosystem". The strategy papers and discussions on the topic have proposed many such changes. Clinical practices and information systems are urged to be reconfigured so that data collection, management, and circulation to the data hubs would become a key task vis-á-vis patient treatment (MSH, 2014). For example, hospitals involved in regional biobanks have complemented their daily clinical routines with practices to inform patients about biobank participation, collect consents and tissue samples, and submit samples and patient data to the biobank. More generally, modifications to information-processing systems and clinical inscription practices have been demanded and initiated throughout the Finnish health care system to make them compatible with large-scale data collection, circulation, and appropriation for data-driven personalized medicine.

Strategy papers and advocates of personalized medicine have also suggested that hospitals and health care centres be "iterated" to be more adaptive to experiments that "translate" genomics, advanced data analytics, or novel digital health technology into clinical practice. Many projects responding to this call are already under way. For instance, the GeneRISK project provides research subjects with a personal genetic risk score for a cardiovascular event by combining genomic and other data. In some cases, the risk score is also mediated to electronic patient records in health care (http://www.generisk.fi). The extension of clinical trials and data appropriation to basic health care centres is planned and being prepared in collaboration with medical companies as a part of the Health Capital 
Helsinki initiative (http://www.healthcapitalhelsinki.fi/en/). In addition, Uusimaa Health Care District (HUS) is creating an "ecosystem" of digital health technology and opening up university hospital clinics to private companies to develop and test their data-management technologies (Tekes, 2017). In these exemple projects, existing institutions and medical practices are captured by experimentality as they are modified to adopt tasks and procedures that serve the development of and experimentation with data-driven medicine.

Finally, many strategy papers and statements by the advocates of personalized medicine express that ethical procedures, regulations, and legislation related to the collection, storage, and appropriation of health data need to be updated to enable more intensive utilization of Finnish databases and biobanks by academic and commercial R\&D. This demand for enabling regulation is the third action framing. As often repeated in the Finnish discussion, "There is a danger that huge investments in health which Finland has made during the past decades will become futile if legislations and [regulative] structures are not determinedly developed from a perspective of research and its commercialization" (MEE, 2014).

The enabling regulation to create and sustain competitiveness is an important element of the innovation policy. An example of this is the legislation for the secondary uses of social and health care data, which is aimed at supporting the building of the national health data hub. The legislative process was hurried, and the law is expected to be put into force in the beginning of 2018 (MSH, 2017).

\section{Discussion}

We have analysed how medical genomics, biobanks, and biomedicine have been promoted in Finland within a sociotechnical imaginary (Jasanoff, 2015a) of personalized 
medicine. We identified two rhetorical framings within which expectations, pursuits, plans, and activities for advancing personalized medicine are connected into a reasonable and justifiable endeavour: innovation policy and data-driven medicine. During the past decade, these framings have intensified and become predominant. First, the promise of personalized medicine today is defined more in terms of wealth than health. The visions of advances in medical science and care have been eclipsed by expectations of business opportunities and commercial collaboration with Big Pharma and international investors. Second, the focus in promoting the future of genomics-based personalized medicine has shifted from molecular biology and tissue samples to the management of a variety of health-related data, of which biological specimens are just a part.

These tendencies have not merely grown out of the dynamics of biomedicine. In this paper, we emphasize that these shifts are being initiated and facilitated by reasoning, practices, pursuits, and tinkering required to sustain the promise of personalized medicine. In addition to the visions of the future, the sociotechnical imaginary of personalized medicine and the expectations it carries are kept alive and credible not only by the grand visions of the future but essentially by concrete strategies, plans and roadmaps, alliance-making, and projects in which new technologies and practices are experimented with, demonstrated, and implemented. We identified three action framings that articulate, in our case, the practical aspect of sociotechnical imaginary and expectations. They are particularly important because they initiate and steer activities that maintain the expectations about personalized medicine by seeking opportunities, harnessing prospects, and mobilizing resources and potential. In addition, the action framings and the practices they promote or are associated with include an aspect of experimenting with existing political, legal, economic, epistemic-technical, professional, and even ethical orders, and they deal with uncertainty and even the unknown associated with experimenting (Helén, 2013). 
Our analysis shows that defining concrete objectives, roadmaps, and milestones; demonstrating actual outcomes; and proceeding step by step in a flexible way are core characteristics of governance that creates the future of personalized medicine and keeps up expectations. To make the vision and promises effective, policy-making ha to attach them to concrete projects and plans that may show actual achievements in a reasonable timeframe and to actual outcomes that demonstrate advances in personalized medicine. However, the outcomes and achievements tend to be secondary and subsumed to the activities of maintaining expectations and creating further opportunities ; in other words, actual scientific, technological, or clinical advances have primarily a performative value as they testify to the emergence of personalized medicine.

Practices and efforts we analyzed have to be flexible because they hold together great visions and concrete strategies, plans for experimentation and implementation and the tentative outcomes of R\&D or clinical implications. Therefore, governance of and by expectations is contextual; it works by iterating and navigating, and it requires improvisation and approximations. Consequently, the imaginary of personalized medicine appears to be malleable and inclined to permanent redefinition. In the Finnish policy discourse and discourse among experts, the core meaning of personalized medicine is detached from molecular genomics and biology. Instead, the collection and analysis of all kinds of personal health-related data by means of advanced bioinformatics are seen as the key factors in the development of more precise and individually tailored medical care. Additionally, the idea of biobanks and biobank infrastructures is being replaced by visions of health data hubs and their networks. The change of focus in the Finnish discourse is congruent with an international trend in the past decade to merge the idea of personalized medicine with the idea of data-driven medicine (NAS, 2011; Prainsack, 2017; Swan, 2012; Weber, Mandl \& Kohane, 2014). The facilitation of access to health databases, creation of opportunities for 
their wider use, and harnessing of new sources of health-related data have become key objectives of promoting personalized medicine - in Finland and elsewhere.

Our analysis also points out that due to its iterative, flexible and "opportunistic" character, promotion of biomedicine is almost inevitably fused with politicization of the sociotechnical imaginary of personalized medicine. This does not mean that advocates of medical genomics solely lobby politicians and policymakers and try to acquire support and financing for biobanks and research projects (cf. Brown et al. 2000). Rather, personalized medicine has become an important policy matter and an object of interest to policymakers, especially within the realm of innovation policy. Today, expectations regarding personalized medicine are not primarily contextualized in the areas of biomedical research and health care; instead, the discourse and rationale of innovation policy redefine what personalized medicine is, its potential and worth, and how it is discussed. An excerpt from a talk by the minister of economic affairs and employment epitomizes the current situation, in which top ministry officials, program directors of think tanks like Sitra, and politicians are voicing the objectives and value of the creation of a medical future, even though the essential knowledge and expertise are derived from practitioners of biomedical science and medical business:

Finland has invested in health-related science, research and education, as well as to research infrastructures and extensive public health care system for decades. Now these investments are starting to bear fruit not only in health care but also as a source for innovation, business opportunities, jobs and economic growth. . . . Boosting health sector growth is one of the key priorities in our overall growth policy. We are building on our strengths; thus digital health and personalized medicine are at the core of the growth strategy. (Rehn, 2016) 
In this setting, the collection and management of Finnish health data in and via data hub is primarily an economic matter. It is emphasized that facilitating $R \& D$ in personalized medicine may reduce the costs of public health care and, in particular, create business opportunities and alliances that would boost the growth of the Finnish health sector. Today, similar economic assumptions underpinning an emerging technology are also common elsewhere and in other domains of technoscience (Birch, 2017). In addition, promoting datadriven personalized medicine is predominantly defined as a national cause. Finland is considered to have assets in its population, databases, and public health care system for international competition, and such national resources, "a treasure", should be embraced and utilized by national endeavours that would bring together all Finnish stakeholdersresearchers, commercial stakeholders, the state, and local public institutions.

A key element in the rationale of boosting biomedical innovation is the view that Finland needs to "grow into an internationally interesting partner in genomics research and genomics-related enterprise" (MSH, 2015, p. 3). Within the innovation policy framing, this objective is inseparably political, economic, and scientific (see also Birch 2017; Muniesa 2017). Our analysis of roadmaps, suggestions, and actions to reach this objective show that the iteration, flexibility, and malleability of governance also create tensions, fuzziness, and disorientation. This side is indicated in, for example, the often repeated claims or even imperatives of Finnish strategy papers and by advocates of personalized medicine that everything has to be done fast because "the window of opportunity for exploiting Finland's strengths will be open for a few years at best" (STM, 2015, p. 3). From every corner of the Finnish biomedical "innovation ecosystem" arise demands for policymaking on personalized medicine to move quickly in removing legislative, regulatory, and ethical obstacles from a more extensive collection of tissue samples and health data and from creating wider access to and deployment of the Finnish population and health databases. Such a rush is justified by 
appealing to necessity and urgency to enhance business opportunities and commercial collaboration between Finnish stakeholders and international enterprises and investors. Although innovation policy for personalized medicine is future oriented, it seems that the present moment matters most: it is right now (or never) that the medical future ought to be made.

Besides hurry, politics and policymaking on data-driven personalized medicine are characterized by uncertainty and confusion. This is also due to the multitude of parallel and overlapping strategies, such as the Health Sector Growth strategy, the Genome Strategy, and the legislative reform on the secondary use of data. Despite the roadmaps and action plans they have presented in reports and PowerPoint presentations, the stakeholders that participated in drafting the plans do not seem to have a clear picture of what actions will be taken next or what the outcomes of their strategies will be. Experts attending seminars and workshops wonder what exactly the Genome Centre will be, what the role of regional biobanks will be, and how the national Health Data HUB will relate to planned biobank fusion, and they are worried about the integration of ICT systems for managing health data. Discussions on these questions reflect differences of opinion and even disagreements, but this is also a sign of genuine confusion about the actual nature, objectives, and benefits of the innovation process. Such confusion is fuelled by the fact that attempts to bring genuine applications of data-driven genomics and e-health to clinics are experimental and embryonic, and the advocacy of personalized medicine appears to be out of step regarding how quickly data-driven approaches and techniques can be implemented into the health care system and clinical practices. Similar features are found to plague health technology development in general, indicating misalignments, confusion and poor functioning of innovation processes and milieus (Greenhalg 2018; Lehoux et al., 2017). 
Our analysis highlights that the practices of governance and policy-making for promoting and making up a medical future keep the sociotechnical imaginary malleable. Expectations and visions of the future of biomedicine are not rigid and static but are continuously under transformation. In Finland, several initiatives and activities in biomedicine have been launched under the title of "personalized medicine." As they are carried out, these activities change the very meaning of what the imaginary of personalized medicine entails. Internationally, this sociotechnical imaginary is about to be hijacked by the growing emphasis on health-related data and digitalization, and the promises of personalized medicine seem to be merging with visionary landscapes of the emerging digital data economy (e.g., Prainsack, 2017). Also, efforts in Finland to maintain the promise of personalized medicine are rearranging the idea and future vision surrounding data-driven medical business. The imaginary of personalized medicine is then being deployed to build a future that seems to be less about citizens' health services and more about building a route for Finland to become the "Silicon Valley" (e.g., Heino, 2016) of health technology, health data, and medical applications of artificial intelligence. Consequently, despite its promises for public and personal benefits, personalized medicine seems to be about building a new national economic flagship.

\section{References}

Bevir, M. (2012). Governance: A very short introduction. Oxford, United Kingdom: Oxford University Press. 
Birch, K. (2017) Techno-economic assumptions. Science as Culture 26(4), 433-444. doi: $10.1080 / 09505431.2017 .1377389$

Borup, M., Brown, N., Konrad, K., \& Lente, H. V. (2006). The sociology of expectations in science and technology. Technology Analysis \& Strategic Management, 18(3-4), 285-298. https://doi.org/10.1080/09537320600777002

Brown, N. (2003). Hope against hype-Accountability in biopasts, presents and futures. Science Studies, 16(2), 3-21.

Brown, N., Rappert, B. \& Webster, A. (2000). Introducing contested futures: From looking into the future to looking at the future, In N. Brown, B. Rappert \& A. Webster (Eds), Contested Futures. (pp. 3-20). Aldershot: Ashgate.

Brown, N., \& Michael, M. (2003). A sociology of expectations: Retrospecting prospects and prospecting retrospects. Technology Analysis \& Strategic Management, 15(1), 3-18. https://doi.org/10.1080/0953732032000046024

Burke, W., Burton, H., Hall, A. E., Karmali, M., Khoury, M. J., Knoppers, B., ... \& Zimmern, R. L. (2010). Extending the reach of public health genomics: What should be the agenda for public health in an era of genome-based and "personalized" medicine? Genetics in Medicine, 12(12), 785-791.

Cappellin, R., \& Wink, R. (2009). International knowledge and innovation networks. Cheltenham, United Kingdom: Edward Elgar.

Cooke, P. (2007). Growth cultures. The global bioeconomy and its bioregions. London, United Kingdom: Routledge.

Cool, A. (2016). Detaching data from the state: Biobanking and building Big Data in Sweden. BioSocieties, 11(3), 277-295. https://doi.org/10.1057/biosoc.2015.25 
Deschamps, J.-P., \& Nelson, B. (2017). Innovation governance: How top management organizes and mobilizes for innovation. Hoboken, NJ: Wiley \& Sons.

Douglas, C. (2014). The role of bioinformatics in facilitating translational science and medicine. Technoscienza, 5, 141-163.

European Commission. (2013). Use of '-omics' technologies in the development of personalised medicine. (Commission staff working document). Retrieved from https://ec.europa.eu/health/sites/health/files/files/latest_news/201310_personalised_medicine_en.pdf (accessed 1.3.2017).

European Science Foundation. (2012). Personalised medicine for the European citizen. Towards more precise medicine for the diagnosis, treatment and prevention of disease (iPM). ESF Forward Look. European Science Foundation, Strasbourg.

Finnish Government, Government Communications Department. (2016, May 4). Government agrees General Government Fiscal Plan for 2017-2020 Press release 135/2016, 5.4.2016 21.30. Retrieved from http://valtioneuvosto.fi/artikkeli/lasset_publisher/10616/hallitus-sopi-julkisen-talouden-suunnitelmasta-vuosille-20172020?_101_INSTANCE_3wyslLo1Z0ni_languageId=en_US

Fischer, F. (2003). Reframing public policy. New York, N.Y.: Oxford University Press.

Fischer, M., Suarez-Villa, L. \& Steiner, M. (Eds.). (1999). Innovation, networks and localities. Berlin, Germany: Springer Science \& Business Media.

Fortun, M. (2008). Promising genomics: Iceland and deCODE genetics in a world of speculation. Berkeley, CA: University of California Press.

Fujimura, J. H. (2003). Future imaginaries: Genome scientists as sociocultural entrepreneurs. In A. H. Goodman, D. Heath, \& M. S. Lindee (Eds.), Genetic nature/culture: Anthropology and science beyond the two-culture divide (pp. 176-199). Berkeley, CA: University of California Press. 
Gissler, M., \& Haukka, J. (2004). Finnish health and social welfare registers in epidemiological research. Norsk Epidemiologi, 14(1), 112-113.

Greenhalgh, T., Fahy, N. \& Shaw, S. (2018) The bright elusive butterfly of value in health technology development. International Journal of Health Policy Management 7(1), 81-85. doi: 10.15171/ijhpm.2017.65

Guttmacher, A. E., \& Collins, F. S. (2005). Realizing the promise of genomics in biomedical research. JAMA, 294(11), 1399-1402.

Hajer, M. (2003). A frame in the fields: Policy making and the re-invention of politics, In M. Hajer \& H. Wegenaar (Eds.) Deliberative policy analysis: Understanding governance in the network society (pp. 88-110), Cambridge: Cambridge University Press

Hamburg, M. A., \& Collins, F. S. (2010). The path to personalized medicine. The New England Journal of Medicine, 363, 301-304. https://doi.org/10.1056/NEJMp1006304

Hedgecoe, A. (2004). Politics of personalized medicine. Cambridge, United Kingdom: Cambridge University Press. https://doi.org/10.1017/CBO9780511489136

Heino, E. (2016). IBM investoi Suomeen: meistä tulee tekoälyn piilaakso. Mediuutiset 14.9.2016. Retrieved from http://www.mediuutiset.fi/uutisarkisto/ibm-investoisuomeen-meista-tulee-tekoalyn-piilaakso-6582669.

Helén, I. (2004). Health in prospect. High-tech medicine, life enhancement and the economy of hope. Science Studies, 17(1), 3-19.

Helén, I. (2013). Elämän politiikka biologisen muokattavuuden aikakaudella: ensimmäinen kartoitus. Sosiologia, 50(4): 327-341. Retrieved from http://www.doria.fi/handle/10024/104174 (accessed 10.11.2017)

Hood, L., \& Friend, S. H. (2011). Predictive, personalized, preventive, participatory (P4) cancer medicine. Nature Reviews Clinical Oncology, 8(3), 184-187. 
Hulst, M. van \& Yanow, D. (2016) From policy "frames" to "framing": Theorizing a more dynamic, political approach. American Review of Public Administration 46(1), 92112.

Hämäläinen, H. (2016, October 28). Sote-tiedon toissijaista käyttöä koskeva lainsäädäntöhanke ja eettiset toimikunnat. Presentation at Lääketieteellisen tutkimusetiikan seminaari, Helsinki, Finland.

Jasanoff, S. (2015a). Future imperfect. In S. Jasanoff \& S.-H. Kim (Eds.), Dreamscapes of modernity. Sociotechnical imaginaries and the fabrication of power. (pp. 1-33). Chicago, IL: University of Chicago Press. https://doi.org/10.7208/chicago/9780226276663.003.0001

Jasanoff, S. (2015b). Imagined and invented worlds. In S. Jasanoff \& S.-H. Kim (Eds.), Dreamscapes of modernity. Sociotechnical imaginaries and the fabrication of power. (pp. 321-341). Chicago, IL: University of Chicago Press. https://doi.org/10.7208/chicago/9780226276663.003.0015

Jasanoff, S., \& Kim, S.-H. (2009). Containing the atom: Sociotechnical imaginaries and nuclear power in the United States and South Korea. Minerva, 47(2), 119-146. https://doi.org/10.1007/s11024-009-9124-4

Jasanoff, S., \& Kim, S.-H. (2015). Dreamscapes of modernity: Sociotechnical imaginaries and the fabrication of power. Chicago, IL: University of Chicago Press. https://doi.org/10.7208/chicago/9780226276663.001.0001

Jessop, B. (1998). The rise of governance and the risks of failure: The case of economic development. International Social Science Journal, 50(1): 29-45.

Jessop, B. (2002). Governance and metagovernance: On reflexivity, requisite variety, and requisite irony. Department of Sociology, Lancaster University, Lancaster, United 
Kingdom. Retrieved from http://www.comp.lancs.ac.uk/sociology/papers/JessopGovernance-and-Metagovernance.pdf

Käpyaho, K., Peltonen-Palotie, L., Perola, M., \& Piispanen, T. (2004). Suomalaiset geenit hyötykäyttöön. Tieteessä tapahtuu, 8, 5-11.

Lander, E. S. (2011). Initial impact of the sequencing of the human genome. Nature, 470(7333), 187-197.

Lauss, G., Snell, K., Bialobrzeski, A., Weigel, J., \& Helén, I. (2011). Embracing complexity and uncertainty: An analysis of three orders of ELSA research on biobanks. Genomics, Society, and Policy, 7(1), 47-64.

Lehoux, P., Mille, F, Daudelin, G.\& Denis, J-L. (2017) Providing value to new health technology: The early contribution of entrepreneurs, investors, and regulatory Agencies. International Journal of Health Policy Management 6(9), 509-518. doi: 10.15171/ijhpm.2017.11

Lehtimäki, H. et al. (in press). Title. Name of the Journal. Retrieved from www.xxxx.com

Lente, H. van. (2012). Navigating foresight in a sea of expectations: Lessons from the sociology of expectations. Technology Analysis \& Strategic Management, 24(8), 769782. https://doi.org/10.1080/09537325.2012.715478

Leonelli, S. (2013). Global data for local science: Assessing the scale of data infrastructures in biological and biomedical research. BioSocieties, 8, 449-465. https://doi.org/10.1057/biosoc.2013.23

Leonelli, S. (2016). Data-centric biology: A philosophical study. Chicago, IL: University of Chicago Press.

Ministry of Economic Affairs and Employment. (2014). Health sector growth strategy for research and innovation activities (Ministry of Economic Affairs and Employment 2014 reports 16/2014). Retrieved from 
http://tem.fi/documents/1410877/3437254/Health+Sector+Growth+Strategy+for+Res earch+and+Innovation+Activities+26052014 (accessed 24.01.2017)

Ministry of Economic Affairs and Employment. (2016). Innovating together. Growth strategy for health sector research and innovation activities: The roadmap for 20162018 (Ministry of Economic Affairs and Employment guidelines and other Publications 8/2016). Retrieved from http://urn.fi/URN:ISBN:978-952-327-142-5 (accessed 24.01.2016)

Ministry of Health. (2017). National strategy for personalized medicine 2017-2020.

Retrieved from http://www.sum.dk/ /media/Filer\%20\%20Publikationer_i_pdf/2017/Personalised-MedicineSummary/SUM_klar_diagnose_summary_UK_web.ashx (Accessed 27 Feb 2017) Ministry of Social Affairs and Health. (2011a). Investointi kestävään terveyteen ja hyvinvointiin. Sosiaali- ja terveysministeriön hallinnonalan tutkimus-, kehittämis- ja innovaatiotoiminnan linjaukset [Investment in sustainable health and welfare: Guidelines for research, development and innovation in social welfare and health care] (Ministry of Social Affairs and Health publications 7/2011). Retrieved from http://urn.fi/URN:ISBN: 978-952-00-3140-4 (Accessed 24 Jan 2017).

Ministry of Social Affairs and Health. (2011b, October 1). Biobank Act sets new standards on research use of samples of human origin (News item N5-57055). Retrieved from http://stm.fi/en/article/-/asset_publisher/biobank-act-sets-new-standards-on-researchuse-of-samples-of-human-origin (accessed 24 Jan 2017)

Ministry of Social Affairs and Health. (2015). Improving health through the use of genomic data. Finland's genome strategy. Working group proposal (Ministry of Social Affairs and Health Raportteja ja muistioita 34/2015:34). Retrieved from http://www.julkari.fi/handle/10024/126940 (accessed 24 Jan 2017) 
Ministry of Social Affairs and Health. (2016a). Sosiaali- ja terveydenhuollon asiakas- ja potilastiedon toissijaista käyttöä koskevaa lainsäädäntöä valmisteleva työryhmä (Working Group intermediary report [Working group preparing the legislation for the secondary uses of the customer and patient data from social and health care]).

Retrieved from http://stm.fi/documents/1271139/3091050/Raportti-

lakity\%C3\%B6ryhm\%C3\%A4n-ty\%C3\%B6st\%C3\%A4-Sote-tietojentietoturvallinen-hy\%C3\%B6dynt\%C3\%A4minen.pdf/1d3541f6-f98b-4129-9bfb5974d3883aea (accessed 10 Nov 2017)

Ministry of Social Affairs and Health. (2016b). Report of the expert group appointed to evaluate the integration of Finnish biobanks. A report to the Ministry of Social Affairs and Health.

Ministry of Social Affairs and Health. (2017, October 26). New licensing authority to streamline the secure use of health and social data (Press release 154/2017). Retrieved from http://stm.fi/en/artikkeli/-/asset_publisher/uusi-lupaviranomainensujuvoittaa-sosiaali-ja-terveystietojen-tietoturvallista-kayttoa (accessed 03 Nov 2017) Muniesa, F. (2017) On the political vernaculars of value creation. Science as Culture 26(4), 445-454. DOI: 10.1080/09505431.2017.1354847

National Academy of Sciences. (2011). Toward precision medicine. Washington, DC: The National Academies Press.

Novas, C. (2006). The political economy of hope: Patients' organizations, science and biovalue. BioSocieties, 1(03), 289-305. https://doi.org/10.1017/S1745855206003024

Organization for Economic Co-operation and Development. (2013). Integrating personalised medicine into health care: Opportunities and challenges. In ICTs and the health sector: Towards smarter health and wellness models. Paris, France: OECD Publishing, Paris. doi:http://dx.doi.org/10.1787/9789264202863-8-en 
Ong, A. (2016). Fungible life. Experiment in the Asian city of life. Durham, NC: Duke University Press.

Palotie, A., \& Peltonen-Palotie, L. (2004). Pitäisikö perustaa suomalainen biopankki? Duodecim, 2004(120), 1710-1712.

Petryna, A. (2009). When experiments travel. Clinical trials and the global search for human subjects. Princeton, NJ: Princeton University Press. https://doi.org/10.1515/9781400830824

Porter, M. (1998). Clusters and competition: New agendas for companies, governments, and institutions. In On competition (pp. 197-287). Boston, MA: Harvard Business School Press.

Prainsack, B. (2017). Personalized medicine: Empowered patients in the 21st century. New York, NY: New York University Press.

Rehn, O. (2016). Minister of Economic Affairs Olli Rehn: Finnish government actions to boost health industry growth. An opening speech by the minister of Economic Affairs and Employment. Brain diseases - Symposium, Helsinki 14 Oct 2016. Retrieved from: https://tem.fi/en/article/-/asset_publisher/ minister-of-economic-affairs-ollirehn-finnish-government-actions-to-boost-health-industry-growth (accessed $22 \mathrm{Feb}$ 2017),

Rickne, A., Laestadius, S., \& Etzkowitz, H. (Eds.). (2012). Innovation governance in an open economy. London, United Kingdom: Routledge.

Rose, H. (2003). The commodification of virtual reality: The Icelandic Health Sector Database. In A. H. Goodman, D. Heath, \& M. S. Lindee (Eds.), Genetic nature/culture: Anthropology and science beyond the two-culture divide (pp. 77-94). Berkeley, CA: University of California Press.

Schön, D.\& Rein, M. (1994). Frame reflection. New York, N.Y.: Basic Books. 
Sitra. (2015). Finland-Your test bed for next generation research and medical innovation [PowerPoint presentation]. Retrieved from https://www.sitra.fi/uutiset/varasta-tamauusi-esitys-vie-suomen-genomiosaamisen-maailmalle/ accessed 10.11.2017

Snell, K. (2009). Social responsibility in developing new biotechnology: Interpretations of responsibility in the governance of Finnish biotechnology (Research report no. 258). University of Helsinki, Department of Sociology, Helsinki, Finland: Helsinki University Print.

Suárez-Diáz, E. (2010). Making room for the new faces: Evolution, genomics and the growth of bioinformatics. History and Philosophy of Life Sciences, 32, 65-89.

Sunder Rajan, K. (2006). Biocapital: The constitution of postgenomic life. Durham, NC: Duke University Press. https://doi.org/10.1215/9780822388005

Swan, M. (2012). Health 2050: The realization of personalized medicine through crowdsourcing, the quantified self, and the participatory biocitizen. Journal of Personalized Medicine, 2, 93-118. https://doi.org/10.3390/jpm2030093

Tekes. (2016). Finland and IBM partner to develop personalized health care and spark economic growth with Watson [Press release]. Retrieved from https://www.tekes.fi/en/whats-going-on/news-2016/finland-and-ibm-partner-todevelop-personalized-healthcare-and-spark-economic-growth-with-watson/ (accessed 1 March 2017)

Tekes. (2017). Launching a new ecosystem of digital health innovations [Press release]. Retrieved from https://www.tekes.fi/en/whats-going-on/news-2017/launching-a-newecosystem-of-digital-health-innovations/ accessed 10 Nov 2017

Topol, E. (2012). The creative destruction of medicine. How the digital revolution will create better health care. New York, NY: Basic Books. 
Tupasela, A. (2006). Kudostalous ja kaupalliset mallit biolääketieteellisen tutkimuksen muuttuvat ehdot. tiede \& edistys, 31(2), 105-118. Retrieved from http://elektra.helsinki.fi/se/t/0356-3677/31/2/kudostal.pdf

Tupasela, A., Snell, K. \& Cañada, J. (2015). Patients, business and the state-Translating health information into sustainable benefits-Policy brief for engagement practices in Canada, Finland, Iceland, Spain, UK and the US (Tekes Review 322/2015). Helsinki, Finland: Tekes.

Tutton, R. (2014). Genomics and the reimagining of personalized medicine. Surrey, United Kingdom: Ashgate Publishing.

Weber, G., Mandl, K., \& Kohane, I. (2014). Finding the missing link for big biomedical data. JAMA, 311(24), 2479-2480. https://doi.org/10.1001/jama.2014.4228

Zerhouni. E. (2005). Translational and clinical science. Time for a new vision. New England Journal of Medicine, 353, 1621-1623. https://doi.org/10.1056/NEJMsb053723

\section{Webpages}

Finland Health: http://www.finlandhealth.fi/-/solution-for-personalized-healthcare, accessed 15 November 2016

Health Capital Helsinki Initiative: http://www.healthcapitalhelsinki.fi/en, accessed 20 February 2017

Genome Canada: www.genomecanada.ca, accessed 27 February 2017

Generisk-project: www.generisk.fi, accessed 27 February 2017

Genomics England: https://www.genomicsengland.co.uk, accessed 1 March 2017 
Life Sciences Industrial Strategy UK: www.gov.uk/government/publications/life-sciencesindustrial-strategy, accessed 5 November 2017

Sitra: www.sitra.fi, accessed 1 March 2017

Sitra \& Isaacus: http://www.sitra.fi/en/well-being/well-being-data, accessed 1 March 2017 